\title{
THE ACQUISITION OF SOCIOLINGUISTIC SKILLS OF CROATIAN UNDERGRADUATE STUDENTS OF ITALIAN AS A FOREIGN LANGUAGE
}

\author{
Maria Rugo* \\ Filozofski Fakultet Sveučilišta u Zagrebu
}

In foreign language teaching, the main objective is often a semistandard variety of the language. However, learners should be put in contact with all possible variations, from the diaphasic dimension to the diastratic, from the diametric to the diatopic (Udier \& Gulešić Machata, 2011).

Among all variations, the diaphasic dimension is very difficult to acquire and is the one which mainly concerns the use of language in relation to different interactional situations. In fact, it is easier to absorb diaphasic varieties in the spontaneous acquisition process than in guided learning (for the difference between these two see Medved Krajnović, 2010). Indeed, although many foreign learners have already assimilated the rules of a certain standard language, it is still difficult for them to acquire a more informal spoken language or to use different linguistic registers (Pallotti, 2000).

This study presents an analysis of the ability of Croatian students to use the Italian language in different interactional registers, in particular the most colloquial and everyday spoken variety. For the purposes of this study, written works and oral productions of Croatian undergraduate students of Italian between the third and fifth year of study have been examined by observing their productive capacities in the stylistic field, especially at the lexical level, but also from a structural and morphosyntactic point of view.

The aim was to establish if these linguistic productions are suitable for real communicative situations in the Italian diaphasic range. Although different registers are not entities with clearly delimitable boundaries (Rovere, 2011), sociolinguistic competence, both productive and receptive, must be one of the main objectives of language teaching. A good sociolinguistic awareness is in fact synonymous with linguistic mastery.

In addition to giving a general overview of the competence of Croatian students, our goal was also to examine which means appear to be the most effective for the needs of the mentioned students.

Keywords: diaphasia, diastratia, linguistic variations, teaching of Italian LS

\section{INTRODUCTION}

One of the most complex aspects of teaching a language to foreigners is certainly to didactically convey its varieties. In general, we tend to teach the standard version of a language, but in this way the learner does not have the opportunity to learn how to manage a formal context or, for example, how to feel comfortable in an informal conversation. In fact, "it is not enough to know the language, one must know which language to use when, where and with whom" (Coveri, Benucci \& Diadori, 1998: 10).

\footnotetext{
mariarugo@gmail.com
} 
The present study examines two types of written exercises, a tourist itinerary and an Italian subtitling work of Croatian films. In the first case, the linguistic expression is more formal and expository, whereas the second case features a colloquial language, informal and full of different expressions and idioms.

Taking these linguistic typologies into consideration, it was noted that learners found it difficult to maintain a linguistic register appropriate to the text at hand, which was often too formal for a colloquial situation or, in the other case, too informal for a tourist itinerary.

Therefore, in this case study we want to confirm the importance of a profound knowledge of linguistic variations, so that students are able to independently choose the different linguistic registers, depending on the situation in which they find themselves.

\section{THEORETICAL CONTEXT}

A first sociological vision of language can already be seen in De Saussure, in that in its correspondence between signifier and signified, the signified, which is what we want to express, is full of sociological aspects and varies spontaneously according to the context of communication.

Since the early decades of the twentieth century we begin to speak of "sociological linguistics", but it is in the middle of the century that sociolinguistics begins to take on a value of its own, also thanks to a development of relevant scholarship in France, and in particular to the research of $\mathrm{M}$. Cohen ${ }^{1}$.

Also, thanks to the American linguist William Labov sociolinguistics has become a true science. Labov (1966), in fact, discovers "the ordered heterogeneity of linguistic behavior" (Berruto, 2004), starting to analyze the linguistic variables within the social context in which they are found.

Sociology, therefore, distinguishes itself from linguistics because of its pragmatism, as it refers to concrete speakers and productions set in a given context. The primary objective is to create a link between language, society and culture, since "the variety of the language can act as a social indicator" (Berruto, 2004). During the second half of the twentieth century, Italy represented a fertile ground in the sociolinguistics field, both for the persistence within it of significant post-unitary linguistic differences, and for the numerous discussions on the school system that had to be reconsidered and reconstructed. Among those who have systematized in depth the sociolinguistic situation in Italy are scholars such as Gaetano Berruto, mostly active from the beginning of the 70s until today, and Mari D'Agostino (2007).

$\overline{1 \text { Pour une sociologie }}$ du langage, Paris, Albin Michel, 1956. 


\subsection{The architecture of language and linguistic variety as linguistic repertoire ${ }^{2}$}

The expression linguistic repertoire refers to the various linguistic possibilities present in the language of a community or an individual. Each variation is therefore linked to different social meanings, in the sense that "it is sensitive to the social classes and to the context" (Berruto, 2004). Actually, the variety comes "by innate human species needs of differentiation and identification" (Berruto, 2004).

The varieties of a language refer to different dimensions, exemplified by Gaetano Berruto in a scheme that reconstructs the architecture of contemporary Italian (see Figure 1).

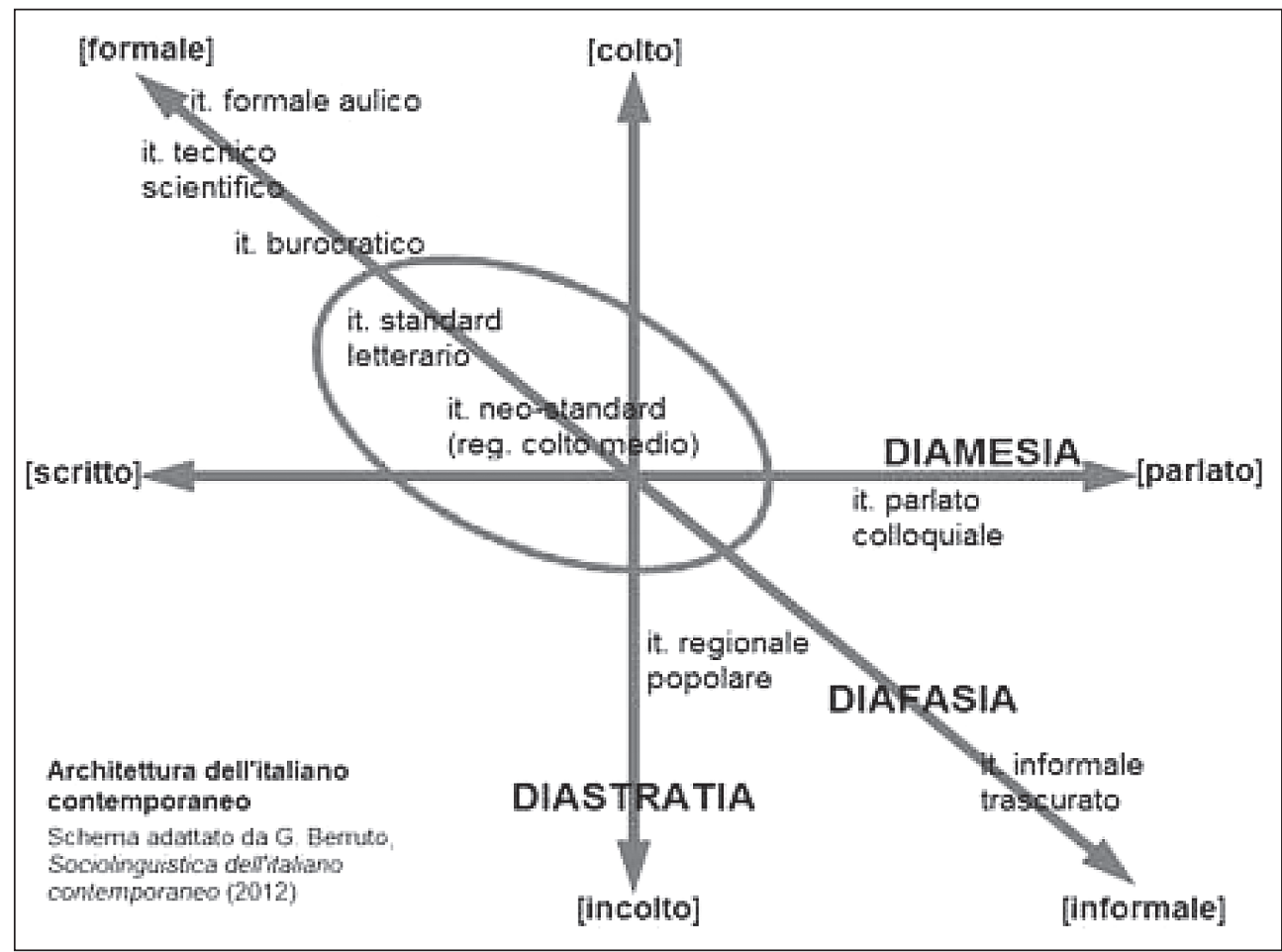

Figure 1. Contemporary Italian Architecture (Berruto, 2012).

The following main synchronic varieties of the language are reported by Berruto: diaphasic (varies according to the communicative situations and to the context), diastratic (varies according to the group or social groups) and diamesic (varies according to the medium in use). They are followed by the diatopic variety (where changes are measured according to the location) and diachronic (varies through time).

${ }^{2}$ Berruto (1993) 
Naturally, the varieties mix together, overlap and are not rigidly separated when it comes to the concrete use of the language, since "the Italian is articulated in well characterized varieties, but not placed in tight compartments" (Sobrero \& Miglietta, 2011).

\subsection{Linguistic varieties in teaching Italian to foreigners}

All language teachers are faced with the same doubts about the type of language to teach, which register to use, whether to leave out the colloquial expressions or not and so on (Udier \& Gulešić Machata, 2011). Most professors decide to teach the standard language, but "variation is a physiological aspect of any living language and it cannot be left out of the language class without limiting [...] the learners' actual communicative success in that language" (Santipolo, 2016).

In any case, the more advanced students use different levels of variation, but without really knowing how to use them, which is why it would be a must to direct the lessons taking care to teach also the linguistic varieties.

Furthermore, in teaching Italian to foreigners, the diastratic and diaphasic dimension should be favored, because it is fundamental for a correct inclusion of the learner into society. It is no coincidence that the diastratic dimension is also defined as a social dimension, in fact "people belonging to the same community differ in the way they speak and [...] this variability is systematically linked to some of their intrinsic characteristics (young / old, inhabitants of the city / of the countryside, educated / uneducated, different professions, etc.)" (D'Agostino, 2011). It is therefore very important to use the appropriate linguistic variety to be able to build social and cultural identity.

Fundamental for a foreign student is also the appropriate use of the diaphasic dimension, otherwise called the situational dimension, because it generally varies according to the situation in which we find ourselves. For example, it particularly varies according to the level of formality.

In this case as well, it is very important to deepen knowledge of this variety, in particular in the teaching of the colloquial variant, in order to put the learner in a position to know how to manage an informal conversation once in Italy, regardless of the social layer of origin of the interlocutor.

As for the high registers, "it is worth [...] remembering that linguistic teaching, in particular the teaching of second languages, is usually based on formal registers; with the inevitable result of a staggering of the communicative competence in foreign languages of those who have learned the foreign language only in a scholastic context, guided" (Berruto, 2012). 


\subsection{Italian neostandard in the language class}

The term neostandard identifies a type of Italian that belongs to the informal registers of speech and that has increasingly gained ground "in the most cultured part of the population. [...] So the standard extends its borders" (Sobrero, 1992).

It is, therefore, a new reference language that exists by now in a constant way from a morphological, syntactic and lexical point of view, which must be available to learners of Italian as a foreign language. Following the classification of Mari D'Agostino (2007), some neostandard traits that have now entered the norm will be listed below. Those traits should be introduced in the standard teaching materials available to Croatian students of Italian as a foreign language

1. Syntax

a. Left dislocation (Il pane, l'hai comprato?)

b. Right dislocation (Non l'ho comprato, il pane)

c. Presentative phrase "C'è" [i.e. "There is"] (C'è uno che ti cerca)

d. Cleft sentence (Sono i vicini a chiamare sempre la polizia)

2. Verbal tenses

a. Imperfect tense expressing courtesy (Volevo chiederti un consiglio...)

b. Imperfect used instead of future in the past (Aveva detto che mi aiutava)

c. Frequency of the impersonal construction in the 3rd person plural (Hanno suonato alla porta)

3. Pronouns

a. Use of lui, lei, loro as subjects

b. Us of gli instead of loro (Ai ragazzi, gli ho detto di venire)

c. Lowering frequence of the relative pronoun il quale, la quale...

$\mathrm{d}$. Use of che as interrogative pronoun, instead of quale (Che macchina vuoi?)

\section{Conjunctions}

a. Che with a consecutive value (Dimmi che ti ascolto)

b. Preference of some subordinating conjunctions, instead of other, for instance siccome and dato che, instead of poiché or giacché.

Therefore, what was considered a few decades ago as entirely incorrect from a grammatical point of view, is now used and accepted by most grammars. Native speakers use the structures analyzed above, so I believe that learners need to be prepared for the possibility of facing these structures. 


\subsection{Material available within the Croatian education system and other considerations}

Aware of the fact that for this topic further specific research on the materials used in the schools should be followed by another scientific paper, I would like to provide a general analysis in this regard.

In Croatia, as far as compulsory education is concerned, most widely used are textbooks published by local publishers, which follow a ministerial program. Here we will not analyze specific textbooks, however we will limit ourselves to pointing out how the sociolinguistic aspect is generally left in the background.

Among the different dimensions, the diamesic is partially used (either very colloquial or very formal), but the consequent lexical choice is not explained to the students, while, actually, the student should be directed to understanding the reason why to opt for one variety rather than another.

Moreover, as has been stated previously, students should be exposed to different varieties of language. It is not enough that the textbooks move on a diamesic dimension. In some manuals, then, there is a predilection on showing off a refined language, in dialogues that should express lexical structures characteristic of the spoken language (e.g.: questo sportelllo si è aperto or ora) or a mixture of refined lexical structures and slang structures in the same context or in the same sentence.

Therefore, in the vast majority of manuals, we notice the tendency to use a more colloquial vocabulary in dialogues between boys and a more formal in adult discussions, but without making it explicit with further exercises that should focus only on the sociolinguistic aspect of the lexicon. It would take more exercises to bring to light, if not all the linguistic variations studied by Berruto, at least that diastratic and diaphasic.

In the dialogues in the textbooks, Croatian scholars have researched in particular the use of discursive signals, such as confirmation signals (vero?) or affirmation (certo che si) etc., analyzing the type of Italian that is taught in Croatian schools, and they have noticed an actual lack of discursive signals. "We can therefore conclude that Croatian editions are predominantly normative in nature and still place greater emphasis on linguistic and less on communication competence." (Mardešić \& Štokovac, 2010).

\section{METHODOLOGY}

\subsection{Subjects}

The study was conducted on a sample of 42 undergraduates studying Italian language and literature at the University of Zagreb. All of the participants are native Croatian speakers and attending the $1^{\text {st }}$ or $2^{\text {nd }}$ year of a Master's degree course (which means $4^{\text {th }}$ and $5^{\text {th }}$ year at the University). The majority 
of them has had a formal education in the Italian language for 3 to 4 years, though some of them have learned the language even before University. Their language competencies can be placed between the B2 and C1 level.

\subsection{Data collection}

The written texts of 42 students in total were analyzed, 22 from the first year and 20 from the second year of the Master's degree course in the Academic Year 2018-2019.

The first year students were tested on their knowledge of neostandard and informal Italian. The text consisted of the translation of subtitles of a Croatian film of their choice, which contained humorous scenes, or scenes in which there were lines with specific cultural references that are more complex to translate into another language.

The second year students were required to create the description of a tourist itinerary in Italy, based on the examples seen in class which referred to a formal vocabulary, specific terminology and medium-high register.

Before these two tests were carried out, the learners were familiarized with the difference between the linguistic registers during each lesson by analyzing in different ways the vocabulary of the texts presented in class. In particular, in the first year of Master's degree course, a lesson was dedicated to the difference between formal, standard and informal vocabulary.

\subsection{Research work plan and instructions given to the students}

Tourism is one of the modules of the first semester of the $2^{\text {nd }}$ year of the Master's degree course.. During the module the city of Venice was presented to the students from different descriptive angles with the aim of deepening their knowledge of a written, formal, relatively refined linguistic register from a diastratic point of view. The examined texts were taken from newspapers such as Il Venerdi di Repubblica and La Nuova Venezia and also literary texts in translation such as the preface of The other Venice by P. Matvejević and the very famous impressions of $\mathrm{H}$. Hesse on the city. After that, students were given the task of describing a brief written tourist itinerary (maximum two pages) within an Italian city of their choice, making a cohesive portrait and paying particular attention to the lexical aspect. It was necessary to use a lexicon for the most part cultured, specific and varied, along the lines of the texts analyzed during the lessons. Later the papers were corrected by highlighting the stylistic inconsistencies, which was done individually by the students to get them to self-correct their work.

A similar exercise has been given in the $1^{\text {st }}$ year of the Master's degree course, during the module on cinema. In this case, however, attention has been focused on more colloquial registers used specifically in oral communication. 
The exercise was of a written type, a sort of subtitling, in which the students were asked to select about ten lines of a Croatian movie of their choice and translate them into Italian. It was important to maintain a linguistic register appropriate to the context and to choose a part where it would be difficult to get the same humor across or to translate a particular cultural expression.

As for the humor in another language other than the original, passages from a didactic text have been selected and analyzed; itexplains the difficulties encountered when it comes to understanding humor in another language, and translating it (Diadori \& Micheli, 2010: 174-175). Moreover, to introduce students to the problem of lexical choices inconsistent with the communicative context, an article was examined in Corriere della Sera by Cesare Segre ${ }^{3}$ concerning the respect of the registers.

And to prepare for the translation work, exercises in textual cohesion (use of linking words) and diaphasic variation were presented; in addition to identifying the communicative situation to which the sentences belong, it was necessary to rewrite them in the most suitable register.

\section{RESULTS}

Based on the results obtained, it was clear that most students are perfectly able to recognize, within a context, the inconsistencies of register between formal and informal language (see example Table 1).

\section{Table 1. Examples Zanichelli ${ }^{4}$}

\begin{tabular}{|l|l|}
\hline $\begin{array}{l}\text { Es: Caro zio, ti devo ringraziare per i preziosi } \\
\text { consigli: senza non me la sarei sfangata } \\
\text { all'interrogazione di storia. }\end{array}$ & $\begin{array}{l}\text { Caro zio, ti devo ringraziare per i preziosi consigli: } \\
\text { senza non avrei preso la sufficienza nell'interrogazione } \\
\text { di storia. } \\
\text { Registro medio- incoerenza di registro: non me la } \\
\text { sareisfangata. }\end{array}$ \\
\hline $\begin{array}{l}\text { a. Tu la devi smettere di spifferare a destra e } \\
\text { sinistra tutto quello che ti dico: ne ricaverei un } \\
\text { irreparabile danno d'immagine. }\end{array}$ & $\ldots$ \\
\hline $\begin{array}{l}\text { b. Gentile cliente, siamo lieti di comunicarle } \\
\text { che sarà gradito ospite del nostro albergo dall'1 } \\
\text { al } 15 \text { agosto; dacci un colpo di telefono per } \\
\text { confermare la preno- tazione. }\end{array}$ & $\ldots$ \\
\hline $\begin{array}{l}\text { c. Mi spiace, ma devo dare un taglio alla storia } \\
\text { con Silvia: invade i miei spazi personali e mi sta } \\
\text { troppo addosso. }\end{array}$ & $\ldots$ \\
\hline
\end{tabular}

Some learners, however, have some difficulty in distinguishing the different registers, without a boundary context and when they are given more than two

\footnotetext{
${ }^{3}$ https://www.corriere.it/cultura/10_gennaio_13/cosi-degrada-la-nostra-lingua-cesare-segre_f86dbfb6-0015-11df-b35f-00144f02aabe.shtml

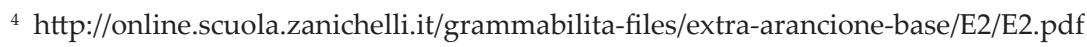


possibilities (formal / standard / informal), for example between "caparbio/ ostinato/testone", or between "frantumare / rompere / fracassare".

The greatest difficulty was found when they had to produce a language with an appropriate register and not only recognize the type of register or correct its stylistic inconsistencies.

When translating the subtitles, in fact, the biggest difficulty was perceived in relation to creating a language appropriate to the source text, informal and colloquial (see examples 4.2.), as well as to using the different varieties of the language. Difficulty also in using the typical syntax of the neostandard Italian (see chapter 2.3. and examples 4.2.).

Regarding the description of a tourist itinerary in Italy, where a more refined language and a more formal result were required, the students found it difficult to keep coherent their stylistic choices and to choose the expressions best suited to the situation (see 4.1.). In fact, it has been noticed that students use typical expressions of speech, different (inappropriate) types of style and a syntax often typical of spoken Italian.

\subsection{Examples taken from students' papers: tourist itineraries}

In this paragraph the results of the analysis of tourist itineraries will be exemplified (see Table 2). Above all, the learners' difficulties in maintaining a register consistency and different style shifts were often detected, caused mainly by too general lexical choices, such as the noun $\cos a$, the verbs dire and fare, the adjective bello or the demonstrative quello. In this type of texts, it would be preferable to use a more specific and more variegated terminology, such as for example the adjectives grazioso, meraviglioso, affascinante, gradevole, ameno, piacevole, etc ... instead of the generic bello. From the stylistic point of view, it is also difficult to list a series of activities or monuments to see in one of the cities described; lexically, the use of a colloquial terminology depreciates the text and it is not suited to the description of a tourist itinerary. In fact, expressions such as farsi una birra, typical of an informal register or the expression porta sfiga, are absolutely unsuitable for a text of this kind.

On the other hand, some students also clearly intend to use a more sophisticated vocabulary, but sometimes exaggerating to the point of using overly refined and almost poetic terminologies (see Tabel 2. - 7).

It is also interesting that they try to recreate a more specific vocabulary using, however, non-existent expressions in Italian; for example, an attempt is made to use a more sophisticated lexicon, such as the adjective avvincente, but it is placed next to the noun pasticcerie; or the adjective distaccato, which contains in itself a metaphorical meaning, and is improperly used to describe monuments far from the Old Town.

From the syntactic point of view, structures more appropriate for an oral discourse (use of the causal introduced by siccome, use of dopo as a coordinating 
and non-subordinating conjunction), are mixed together with more formal structures, such as the subordinate implicit gerunds (see Table 2. - 8).

Table 2. Examples of tourist itineraries

\begin{tabular}{|c|c|}
\hline Comment & Students' examples \\
\hline 1.Lapses of style: Colloquial lexical choices. & $\begin{array}{l}\text { Si piazza } \\
\text { Farsi una birra } \\
\text { Attraversare in diagonale la piazza porta sfiga } \\
\text { Hanno un pezzo di storia interessante } \\
\text { Affamati come lupi } \\
\text { Ci metteremo in coda }\end{array}$ \\
\hline $\begin{array}{l}\text { 2. Lapses of style: use of the colon and lists/ } \\
\text { series. }\end{array}$ & I monumenti più importanti sono:...... \\
\hline $\begin{array}{l}\text { 3. Lapses of style: frequent use of generic } \\
\text { terminologies. }\end{array}$ & $\begin{array}{l}\text { Vedere tante cose } \\
\text { Fare } \\
\text { Dire } \\
\text { Aggettivo bello } \\
\text { Dopo si torna a Marina Grande } \\
\text { Ci sono moltissimi monumenti } \\
\text { Dimostrativo quello }\end{array}$ \\
\hline $\begin{array}{l}\text { 4. Lapses of style: lexical choices not very } \\
\text { suitable and too general. }\end{array}$ & $\begin{array}{l}\text { La città è piena di chiese } \\
\text { Manarola è il villaggio più vecchio }\end{array}$ \\
\hline $\begin{array}{l}\text { 5. Attempts to create a more formal lexicon, } \\
\text { combining together terms that do not form a } \\
\text { collocation. }\end{array}$ & $\begin{array}{l}\text { Monumenti distaccati all'interno del centro } \\
\text { storico } \\
\text { La mattina presto crea un'atmosfera magica } \\
\text { Tutti questi cibi meritano di essere mangiati } \\
\text { Monumenti imperdibili } \\
\text { Pasticcerie avvincenti }\end{array}$ \\
\hline $\begin{array}{l}\text { 6. Use of a frequent lexicon in L1, but not so } \\
\text { frequent in Italian. }\end{array}$ & $\begin{array}{l}\text { Abuso del verbo godere }->\text { godere i concerti, si } \\
\text { gode di splendide casette, rilassati godendo una } \\
\text { birra artigianale italiana,... }\end{array}$ \\
\hline 7. Exaggeration in the too formal lexical choices. & $\begin{array}{l}\text { Non indulgeremo in questa zona } \\
\text { Questa favola inzuppata di serenità } \\
\text { I soprammenzionati faraglioni } \\
\text { Ogni monumento parla a chi si ferma a mirarlo }\end{array}$ \\
\hline $\begin{array}{l}\text { 8. Use of implicit subordinates within a text set } \\
\text { mainly on a standard-colloquial register. }\end{array}$ & $\begin{array}{l}\text { Avendo trascorso una serata divertente, ci } \\
\text { avviamo verso il nostro hotel. }\end{array}$ \\
\hline
\end{tabular}

\subsection{Examples taken from the students' papers: subtitling.}

In this paragraph the results of the analysis of the subtitling translations will be exemplified (see Table 3.).

In general, the difficulty surfaces in sticking to an informal register and choosing a vocabulary suitable for a colloquial situation. For example, it is not correct to translate the slang expression crknuti with the verb funzionare, typical of a standard Italian (Table 3. - 1); in the same way the word lova 
cannot be standardized with Italian denaro or the expression such as brijem, with the simple penso in Italian. In these cases, the register is totally modified.

Then, in some translations, the attempt to make a language more as a slang, though often obtaining inconsistent results, such as in the use of the term ragazzo truncated in a ragà, an unnecessary lexical choice (Table 3. - 6).

In the colloquial language everyone uses a lot of 'pronominal verbs', but in the translations of the subtitles the students have used very little of them (see Table 3. - 11); also difficult is the translation of proverbs, which should not be translated literally, but with an Italian equivalent (Table 3. - 13).

A further difficulty was found in making the syntax of the neostandard Italian, for example in the dislocation of the direct pronoun (see Table 3. - 8).

Therefore, in the translations of the movie dialogues chosen by the learners, one can notice a great difficulty in finding a specific terminology typical of the spoken or jargon language; very often, therefore, a standard translation of colloquial terms prevails, which leads to the loss of most of the nuances of the register.

Table 3. Examples of subtitling

\begin{tabular}{|l|l|l|l|}
\hline Original in Croatian & $\begin{array}{l}\text { Translation in } \\
\text { italian (student) }\end{array}$ & Suggestion & Comments \\
\hline $\begin{array}{l}\text { 1....kosilicu...i crkla je } \\
\text { nakon 3 dana. }\end{array}$ & $\begin{array}{l}\text {...la falciatrice } \\
\text { ha smesso di } \\
\text { funzionare dopo tre } \\
\text { giorni. }\end{array}$ & ...la falciatrice è \\
morta dopo tre giorni & $\begin{array}{l}\text { Need to maintain a } \\
\text { vernacular register } \\
\text { (crknuti), in order not } \\
\text { to lose the sense of the } \\
\text { starting sentence. }\end{array}$ \\
\hline $\begin{array}{l}\text { 2. Ak' ne mremo nikak } \\
\text { drukčije doć do te } \\
\text { love, jebiga, jer bum } \\
\text { bar mirno spaval.... }\end{array}$ & $\begin{array}{l}\text { Se non possiamo } \\
\text { ottenere denaro in } \\
\text { maniera diversa.... }\end{array}$ & $\begin{array}{l}\text { Se non riusciamo ad } \\
\text { avere la grana in altro } \\
\text { modo... }\end{array}$ & $\begin{array}{l}\text { Need to maintain a } \\
\text { vernacular register }(l o v a), \\
\text { in order not to lose the } \\
\text { sense of the starting } \\
\text { sentence. }\end{array}$ \\
\hline 3. Velečasni & Chierico & Padre & $\begin{array}{l}\text { Outdated terminology, } \\
\text { not necessary. }\end{array}$ \\
\hline 4. Svaka čast & Ogni onore & Complimenti & $\begin{array}{l}\text { The translation follows } \\
\text { atoo formal language. } \\
\text { Translation word-by- } \\
\text { word. }\end{array}$ \\
\hline 5. Brijem da... & Penso che... & Mi sa che... & $\begin{array}{l}\text { Need to maintain a } \\
\text { vernacular register } \\
\text { (Brijem). }\end{array}$ \\
\hline $\begin{array}{l}\text { 6. Ti si mnogo } \\
\text { bolestan, dečko. }\end{array}$ & $\begin{array}{l}\text { Sei molto } \\
\text { disturbato, raga'. }\end{array}$ & $\begin{array}{l}\text { Hai qualche } \\
\text { problema, } \\
\text { giovanotto. }\end{array}$ & $\begin{array}{l}\text { Interference of the } \\
\text { English word disturbed. } \\
\text { Unnecessary use of the } \\
\text { abbreviation ragà, which } \\
\text { in Italian is a regionalism. }\end{array}$ \\
\hline 7. Dosta već! & Basta già! & Adesso basta! & $\begin{array}{l}\text { Literal translation of an } \\
\text { expression. }\end{array}$ \\
\hline
\end{tabular}


Rugo: The Acquisition of Sociolinguistic Skills of Croatian ... (str. 61-75)

\begin{tabular}{|l|l|l|l|}
\hline $\begin{array}{l}\text { 8. Zakaj ti to mene } \\
\text { pitaš? }\end{array}$ & $\begin{array}{l}\text { Perché mi chiedi } \\
\text { questo? }\end{array}$ & $\begin{array}{l}\text { Perché lo chiedi a } \\
\text { me? }\end{array}$ & $\begin{array}{l}\text { Wrong word order and } \\
\text { use of pronouns in the } \\
\text { spoken language. }\end{array}$ \\
\hline $\begin{array}{l}\text { 9. ...moreju samo priko } \\
\text { mene mrtve }\end{array}$ & $\begin{array}{l}\text {...posson passar solo } \\
\text { sopra me morta }\end{array}$ & ...che passino sopra il \\
mio cadavere. & $\begin{array}{l}\text { The power of the } \\
\text { exclamation is lost in the } \\
\text { translation. Translation } \\
\text { word-by-word. }\end{array}$ \\
\hline 10. Baš mu je zgodno & $\begin{array}{l}\text { Gli conviene } \\
\text { proprio }\end{array}$ & Per lui è l'ideale & $\begin{array}{l}\text { Literal translation of an } \\
\text { expression. }\end{array}$ \\
\hline $\begin{array}{l}\text { 11. A šta se odmah } \\
\text { uzrujavaš? }\end{array}$ & $\begin{array}{l}\text { Perché ti disturbi } \\
\text { subito? }\end{array}$ & $\begin{array}{l}\text { Perché te la prendi } \\
\text { subito? }\end{array}$ & $\begin{array}{l}\text { Failed in expressing the } \\
\text { colloquial vocabulary. }\end{array}$ \\
\hline $\begin{array}{l}\text { 12. Kaj ti sebi utvaraš? } \\
\text { Cosa ti pensi? }\end{array}$ & Chi ti credi di essere? & $\begin{array}{l}\text { Lack of knowledge of } \\
\text { expressions. }\end{array}$ \\
\hline $\begin{array}{l}\text { 13. ... pravite ražanj, } a \\
\text { zec vam je } u \text { šumi }\end{array}$ & $\begin{array}{l}\ldots \text { state facendo } \\
\text { lo spiedo, però il } \\
\text { coniglio è ancora } \\
\text { nel bosco }\end{array}$ & $\begin{array}{l}\text { Non dite gatto finché } \\
\text { non ce l'avete nel } \\
\text { sacco. }\end{array}$ & $\begin{array}{l}\text { Lack of knowledge of } \\
\text { proverbs, which cannot be } \\
\text { translated literally. }\end{array}$ \\
\hline $\begin{array}{l}\text { 14. A kako ću ih posli } \\
\text { nać ako nemam dobru } \\
\text { memoriju? }\end{array}$ & $\begin{array}{l}\text { E come li troverò } \\
\text { dopo se non ho una } \\
\text { buona memoria? }\end{array}$ & $\begin{array}{l}\text { E come farò a trovarli } \\
\text { dopo, se non ho una } \\
\text { buona memoria? }\end{array}$ & $\begin{array}{l}\text { Typical expressions of } \\
\text { spoken language. }\end{array}$ \\
\hline
\end{tabular}

\section{DIDACTICAL PROPOSALS}

As clearly stated by Sobrero and Miglietta (2011), a valid communicative competence does not consist only of a linguistic competence, but also goes with the sociolinguistic.

For this reason, it is advisable to start from authentic materials and real texts, paying particular attention to give preference to an inductive methodology, which will offer students the opportunity to practice these sociolinguistic skills.

One of the fundamental things that a student must have clear is the fact that there is not only a formal / informal written Italian or a formal / informal oral Italian, but "a stratified language" (Corbucci, 2007). To make learners aware of this, it is necessary to make them aware of the possible varieties, putting them often in contact with a plurality of different texts.

The important thing is to be able to give "useful and usable linguistic and cultural models [....], variable according to the communication needs", it is important that it is "a variety "tailor made on the receiver", teaching "what it is more useful before what is less useful [...], what is more widespread before than what is less widespread" (Santipolo, 2016).

The most useful thing, though, is to put the students in contact with as many situations as possible, but then make them also analyze those situations in depth, anticipating what they will find and face in Italy. Without a detailed analysis of the vocabulary used on various occasions, it is more difficult for them to understand the sociolinguistic level of the situation. 
Explaining, therefore, that Italian is not just a standard language and presenting a plurality of linguistic variations, students are informed and given proof of the fact that it is a stratified language. And then, the more they are able to make this linguistic variety their own, the sooner they will be able to get in touch with the reality of the language actually used.

Surely, criteria of increasing complexity must be respected. For the elementary level it is sufficient to exemplify the situations. At an intermediate level the stylistic rules should be completely understood, even if not easily put into practice. Finally, at the advanced level sociopragmatic competence is required.

\section{SUGGESTIONS FOR FURTHER RESEARCH}

Sociolinguistic competence must be the language teaching objective of every language teacher, since, often, the student makes use of grammatically correct linguistic choices, but which give the listener or reader the impression of impropriety. This is because there is a large number of sociolinguistic variables which should be taken into account when using a language in a particular context.

It would be important to carry out an in-depth analysis of the "conversational patterns" that are "culturally differentiated" (Sobrero \& Miglietta, 2011) between one country and another.

For example, if we compare Italy and Croatia, generally Italians use longer texts. They do not respond in a synthetic way but insert various details, even in oral conversation. Moreover, Italians always elaborate their point of view, they do not simply tell what happened.

Another difference is seen in the emotional involvement, accompanied by various rhetorical artifice, such as exaggeration or dramatization, which in the Croats is much less evident.

Of all the conversational schemes, it's very clear that Italians often interrupt the speaker, for example to show interest, to repeat or add, or to point out to the interlocutor that they are listening to him.

Therefore, a grammatically correct linguistic choice can lead to a sociolinguistic incorrectness much more striking in the eyes of a native speaker.

An analysis of the conversational style used by learners, especially in the oral field, and which covers various areas, is of considerable interest and useful for being able to create new language teaching strategies that take into account sociolinguistic skills.

Analyzing the speech production, perhaps a written report after testing, would contribute to get a broader picture and insight into the results. A constructive written reflection would help the learners to get a better understanding of their patterns and skills from a sociolinguistic point of view. 


\section{CONCLUSIONS}

In conclusion, knowing a language means to be able to communicate, so the more the students are made aware of the sociolinguistic dimension, the more likely it is that the language will be used effectively.

On the other hand, as Santipolo quotes (2016) citing in turn Cicero, variatio delectat, which means that variety is pleasant. That is to say, variations in a language convey liveliness, dynamism and effervescence.

So getting students to acquire a pragmatic language proficiency does not mean making the whole spectrum of varieties known. Everyone is familiar with particular varieties, even in their mother tongue. To acquire a pragmatic competence of the language means, instead, "to recognize the socio-cultural aspects involved in the communication process" (Pizzolo Torquato, 2011).

As stated by Udier and Machata (2011) in the case of the study of Croatian as a foreign language, students at the most advanced levels should be able to handle the highest and lowest varieties of the standard language; and as far as the vocabulary is concerned, they should be able to manage both the standard and the colloquial language.

From what emerged in this case study, I would add that, at least in Italian, learners of more advanced levels must appropriately use numerous varieties of the language, in order to be able to deal with the different sociolinguistic and cultural situations.

Undoubtedly, the more students are faced with different elements of the language, the more they will be able to analyze them, recognize them, and finally make them their own.

\section{REFERENCES}

Berruto, G. (1993) Le varietà del repertorio. In Introduzione all'italiano contemporaneo, a cura di A.A. Sobrero, Roma - Bari, Laterza, 2 voll., vol. $2^{\circ}$ (La variazione e gli usi), 3-36.

Berruto, G. (1990) Varietà diamesiche, diastratiche, diafasiche. In A. Sobrero (eds) Introduzione all'italiano contemporaneo. La variazione e gli usi. Roma-Bari: Laterza, 37-92.

Berruto, G. (2004) Prima lezione di sociolinguistica. Bari: Laterza.

Berruto, G. (2012) Sociolinguistica dell'italiano contemporaneo. Roma: Carocci.

Corbucci, G. (2007) Fenomeni di variazione sociolinguistica nell'insegnamento dell'italiano a stranieri. Studi di glottodidattica 5 (2), 1-23.

Coveri, L., Benucci, A. and Diadori, P. (1998) Le varietà dell'italiano. Manuale di sociolinguistica italiana. Università per Stranieri di Siena. Roma: Bonacci.

D'Agostino, M. (2007) Sociolinguistica dell'Italia contemporanea. Bologna: Il Mulino.

D'Agostino, M. (2011) Variazione diastratica. In Enciclopedia dell'Italiano. Roma: Treccani.

http://www.treccani.it/enciclopedia/variazione-diastratica_(Enciclopedia-dell'Italiano)/ (08/09/2019)

Diadori, P. and Micheli P. (2010) Cinema e didattica dell'italiano L2. Perugia: Guerra Edizioni.

Labov, W. (1966) The social stratification of English in New York City. Washington (D.C.): Center for Applied Linguistics.

Mardešić, S. and Štokovac, T. (2010) Jezik udžbenika: prisutnost sociolingvističkih i pragmalingvističkih elemenata. https://www.academia.edu/10338715/Jezik_ud\%C5\%BEbenika_prisutnost_sociolingvisti\%C4\%8Dkih_i_pragmalingvisti\%C4\%8Dkih_elemenata (20/08/2019) 
Medved Krajnović, M. (2010) Od jednojezičnosti do višejezičnosti: uvod u istraživanja procesa ovladavanja inim jezikom. Zagreb: Leykam international.

Pallotti, G. (2000) La seconda lingua. Milano: Bompiani.

Pizzolo Torquato, C. (2011) Le varietà del repertorio linguistico e l'insegnamento dell'italiano come lingua straniera. Revista de Italianistica 21-22, 153- 160.

Rovere, G. (2011) Registro. In Enciclopedia dell'Italiano. Roma: Treccani, 349-375.

Santipolo, M. (2016) Variatio delectat, ossia della necessità della varietà di modelli sociolinguistici nella classe di lingua. EL.LE [online] 5 (3), 327-338. https://edizionicafoscari.unive.it/media/ pdf/article/elle/2016/3/art-10.14277-2280-6792-ELLE-5-3-0.pdf (08/09/2019)

Sobrero, A. (1992) L' italiano di oggi, Roma, Istituto della Enciclopedia Italiana Treccani.

Sobrero, A. and Miglietta A. (2011) Per un approccio varietistico all'insegnamento dell'italiano a stranieri (parte seconda). ILD - Italiano LinguaDue. http://riviste.unimi.it/index.php/promoitals/ article/view/1924 (28.03.2019)

Udier, S. and Machata Gulešić, M. (2011) Kakvom jeziku poučavati neizvorne govornike?: Viši i niži varijetet u poučavanju hrvatskoga kao inog jezika. Nova Croatica 5 (5), 329-349.

\section{OVLADAVANJE SOCIOLINGVISTIČKIM VJEŠTINAMA HRVATSKIH STUDENATA TALIJANSKOG KAO STRANOG JEZIKA}

U nastavi stranoga jezika često je osnovni cilj usvojiti polustandardni registar. Međutim, učenike je potrebno staviti u kontakt sa svim mogućim varijacijama, od dijafazije do dijastratike, od dijametralne do dijatopijske dimenzije (Udier i Gulešić Machata, 2011).

Od svih varijacija jako je teško ovladati dijafazijom, odnosno dimenzijom koja se uglavnom odnosi na uporabu jezika u odnosu na različite interakcijske situacije. Lakše je apsorbirati dijafazne varijante $\mathrm{u}$ procesu spontanog usvajanja nego u vođenom učenju (za razliku u usvajanju vidjeti npr. Medved Krajnović 2010). Zapravo, mnogi učenici stranog jezika koji su već asimilirali pravila određenog standardnog jezika, i dalje nailaze na poteškoće u primjeni neformalnijeg govornog jezika ili pri korištenju različitih jezičnih registara (Pallotti, 2000).

Ovom se studijom željelo analizirati sposobnost snalaženja hrvatskih studenata $\mathrm{u}$ različitim jezičnim registrima talijanskog jezika, a posebno u najrazličitijim interakcijskim i svakodnevnim situacijama. U obzir su uzeti pisani radovi i usmeno izražavanje studenata talijanistike u Zagrebu između treće i pete godine studija, praćeni su njihovi kapaciteti u stilskom području, osobito na leksičkoj razini, ali i na strukturalnoj i morfosintaktičkoj. Pokušalo se utvrditi jesu li te jezične produkcije prikladne za stvarne komunikacijske situacije koje su dio talijanskog dijafaznog raspona.

Iako registri nisu entiteti s jasno razgraničenim granicama (Rovere, 2011), sociolingvistička kompetencija, i produktivna i receptivna, mora biti jedan od glavnih ciljeva poučavanja jezika. Dobra sociolingvistička svjesnost zapravo je sinonim za tečnost u jeziku.

Uz opći pregled kompetencija hrvatskih studenata, cilj je bio analizirati i koja su sredstva najučinkovitija za potrebe navedenih učenika.

Ključne riječi: lingvističke varijacije, dijafazija, diastratija, učenje talijanskog JS 